\title{
PENGARUH SIKAP PATUH HUKUM, SIKAP TERHADAP LEGALITAS PEMBELIAN, DAN KINERJA PRODUK TERHADAP MINAT UNTUK MEMBELI CD BAJAKAN BERMEREK
}

\author{
Yazid \\ Fakultas Ekonomi Universitas Islam Indonesia \\ Muchsin Muthohar \\ Fakultas Ekonomi Universitas Islam Indonesia
}

\begin{abstract}
'The reasoned-action theory' states that consumer behavior may reflex either individual attitude towards behavior and individual behavior concerning subjective norms. This research is aim to identify the influence of law conformity, attitude towards purchase legality, and the performance of pirated compact disk (CD) product on the consumers' intention to buy pirated-branded $C D$. As many as 500 respondents were taken from five universities in Yogyakarta by quota-convenience sampling method. Regression analysis shows that those three variables simultaneously affect the dependent variables. Its individual affect, however, is different. Law conformity, and attitude towards purchase legality do not affect the dependent variable, meanwhile the performance of CD affect it. Paying attention on the level consumption status of responden, it is found that price and availabity of $C D$ is more important than prestige. In addition, demographic analysis shows that consumption status, group, tradition, and religion do not affect the motivation on purcahsing $C D$.
\end{abstract}

Keywords: behavior, attitude, subjective norm, pirated-branded CD

\section{PENDAHULUAN}

Teknologi dan distribusi sekarang membuat banyak produk mampu menjangkau wilayah yang luas dalam waktu yang relatif cepat, namun produk tersebut makin rawan pembajakan. Olsen \& Granzin (1992); Masland \& Marshall (1990); menemukan bahwa ragam produk yang dibajak mencakup produk mewah hingga produk kebutuhan sehari-hari atau sejak dari produk yang membutuhkan keputusan pembelian yang ekstra hati-hati, seperti suku cadang pesawat terbang dan obat-obatan dengan resep dokter (Bloch, Bush \& Campbell, 1993; dan Harvey \& Ronkainen, 1985), hingga produk yang membutuhkan keputusan pembelian sederhana, seperti produk berupa dompet, sepatu, dan sebagainya (Wee, Tan \& Cheok, 1996).

Kehadiran produk bajakan di pasar telah membuat persaingan bisnis menjadi jauh dari adil. Pabrikan pemegang merek dan paten produk asli harus bersaing dengan pemegang merek lain melalui berbagai strategi (termasuk pemasaran) dengan pengeluaran dana yang tidak sedikit. Sementara pembajak, cukup mendompleng keberhasilan para pemegang merek yang syah dalam membangun image produknya, tidak perlu melakukan investasi yang mahal untuk keperluan kontrol kualitas, tidak memerlukan material yang baik, tidak perlu riset dan pengembangan serta pemasaran. Oleh karena itu para pembajak mampu 
menjual produknya jauh lebih murah dibanding produk aslinya.

Dampak penting dari pembajakan produk mencakup: rusaknya reputasi perusahaan dan merek produk yang dibajak (Nash, 1989; Bazan, 1999; Delener, 2000), turunnya penghargaan terhadap upaya riset dan pengembangan produk, serta meningkatkan biaya untuk menyelesaikan kasus hukum berkait dengan pembajakan dan turunnya laba perusahaan pemegang merek resmi (Nash, 1989; Bloch, Bush \& Campbell, 1993; Bazan, 1999). Bagi konsumen sendiri, produk bajakan dapat membahayakan dirinya akibat dari mengkonsumsi produk dengan kualitas yang tidak baku seperti aslinya, misalnya konsumsi obat bajakan (Nash, 1989; and Wee, Tan \& Cheok, 1995). Akibat lainnya yang dialami oleh pabrikan pemegang merek asli, minimal, berupa penurunan tingkat kepercayaan dari konsumen, sementara pemerintah dirugikan karena kehilangan pemasukan dari pajak (Lynch, 2002 ; dan Vithlani, 1998).

Untuk mencegah kerugian akibat praktek bisnis bajakan dikeluarkanlah Intellectual Property Right (IPR) atau Hak atas Kekayaan Intelektual (HaKI). Upaya penegakan HaKI sudah merupakan agenda internasional. Indonesia sendiri, melalui UU No. 19 tahun 2000 tentang Hak Cipta telah memberantas perdagangan produk bajakan. Namun, ternyata, perang ini tidak mudah untuk dimenangkan. Direktur Jenderal HaKI Departemen Kehakiman RI, menengarai bahwa tidak efektifnya pemberantasan bisnis produk bajakan itu dikarenakan kelemahan penegakan hukum. Padahal, kelemahan penegakan hukum baru merupakan salah satu variabel saja. Variabel lain yang mempengaruhi pembajakan produk misalnya aspek sosial, budaya dan ekonomi (Lai \& Zaichkowski, 1999), rendahnya kesadaran publik terhadap makna kekayaan intelektual (Fareshti N.D., 2003) yang terutama dimiliki oleh konsumen di wilayah Asia, sehingga semakin mempersulit upaya Penegakan HaKI.

Ada dua sisi pandang penelitian bidang pemasaran berkaitan dengan produk bajakan, yaitu penelitian yang difokuskan pada penjual (Bush et al., 1989; Harvey, 1987; dan Harvey \& Ronkainen, 1985), dan penelitian yang difokuskan pada pembeli produk bajakan (Cordel, et al., 1996; dan Lai \& Zaichkowsky, 1999). Temuan dari penelitian mereka masih belum memberikan kontribusi yang cukup signifikan terhadap perkembangan ilmu pemasaran (Field, 2000) dan terhadap efektifitas penerapan peraturan tentang pembajakan.

Kajian empiris menemukan bahwa alasan membeli CD bajakan mengalami pergeseran. Semula, pembelian CD bajakan dilakukan karena alasan finansial. Belakangan diketahui, pembeli CD bajakan adalah juga konsumen yang secara finansial kuat. Kenyataan ini tentu semakin mempersulit upaya pemberantasan produk bajakan, sebab pandangan terhadap CD bajakan yang semula negatif telah berubah menjadi positif atau permisif, terutama karena adanya persepsi berkaitan dengan kinerja CD bajakan yang tidak jauh dari CD aslinya. Tabel di bawah ini menjelaskan pergeseran dimaksud. 
Tabel 1: Pergeseran Motif Pembelian Terhadap Produk Bajakan

\begin{tabular}{|c|c|c|}
\hline No & Peneliti & Hasil kajian \\
\hline 1 & Bloch et al. (1993) & $\begin{array}{l}\text { alasan membeli produk palsu karena kondisi keuangan yang } \\
\text { minim }\end{array}$ \\
\hline 2 & Cordel et al. (1996) & $\begin{array}{l}\text { permintaan produk "haram" dilandasi oleh kinerja produk palsu } \\
\text { sudah sesuai dengan persepsi konsumen, tingkat } \\
\text { perbedaannya tidak jauh dari aslinya }\end{array}$ \\
\hline 3 & Nia \& Zaickowsky (2000) & $\begin{array}{l}\text { konsumen semakin bersikap positif terhadap produk palsu } \\
\text { dengan indikasi bahwa produk palsu itu dipersepsikan tidak } \\
\text { merugikan produk aslinya karena produk palsu posisinya } \\
\text { bersifat inferior terhadap produk asli. }\end{array}$ \\
\hline 4 & $\begin{array}{l}\text { Phau, Prendesgast, dan Cheung } \\
\text { (2001) dan Field (2000) }\end{array}$ & $\begin{array}{l}\text { pembelian produk palsu ternyata didukung oleh referensi dari } \\
\text { keluarga, teman, dan kenyataan bahwa produk tersebut yang } \\
\text { semakin berkualitas }\end{array}$ \\
\hline 5 & d'Astous dan Gargouri (2001) & $\begin{array}{l}\text { konsumen tidak memperdulikan masalah kualitas lagi pada } \\
\text { produk imitasi ini, tetapi melihat reputasi penjualnya atau toko } \\
\text { yang menjaul produk tersebut. Semakin terpercaya penjualnya } \\
\text { semakin positip dampak penjualan produk palsu tersebut } \\
\text { karena penjual diharapkan memberikan informasi yang jujur }\end{array}$ \\
\hline
\end{tabular}

Penelitian terhadap konsumen yang dikaitkan dengan bisnis produk palsu akan sangat kompleks karena melibatkan banyak variabel, seperti etika, integritas, cara konsumen menuhi kebutuhan, dan sebagainya. Lain dari itu pengaruh lingkungan juga tidak kalah kuat, misalnya kebijakan publik yang tidak konsisten; ketidak sungguhan penegakan hukum dan peraturan; ketidakpastian politik dan transparansi ekonomi dan sebagainya (Lai \& Zaickowsky, 1999).

Penjelasan di atas memahamkan bahwa masalah pembajakan merupakan masalah perilaku bisnis yang tidak bisa dilepaskan dari konteks budaya masyarakat yang mencakup nilai-nilai hukum, ekonomi, politik, struktur sosial, agama, pendidikan dan bahasa (Chan, et.al 1998). Secara umum, perilaku masyarakat didasarkan atas nilai-nilai yang dianutnya dalam menjalani kehidupanya. Adapun pengertian "nilai" sendiri dapat diartikan sebagai suatu gambaran -baik implisit maupun ekplisitkhusus dari individu atau kelompok individu tentang karakter mereka yang menonjol dalam mempengaruhi pola pikir, cara bertindak dan hasil akhir yang diinginkan oleh masyarakat tersebut (Hofsted, 2000).
Dengan demikian maka nilai-nilai budaya dapat diartikan sebagai suatu gambaran dari karakter suatu masyarakat. "Perilaku pembajakan produk" merupakan salah satu bentuk karakter yang termasuk dalam definisi di atas. Jadi, nilai-nilai budaya masyarakat juga memiliki dampak terhadap permasalahan usaha pembajakan produk di suatu masyarakat atau wilayah atau negara.

Negara-negara "timur" dikenal memiliki budaya kolektifisme yang kuat, yaitu lebih mendahulukan kepentingan bersama dari pada kepentingan individu, yang secara implisit 'merestui' atau permisif terhadap pembajakan produk apabila memberikan kemanfaatan umum. Kondisi ini memberi peluang besar kepada masyarakat untuk memiliki produk bajakan yang berarti juga 'membantu pertumbuhan ekonomi'. Karena itu kebanyakan "negara tertuduh" pelaku pembajakan adalah di negara-negara timur (Tabel.2). Di pihak lain, negara-negara "barat" memiliki budaya individualisme yang menekankan kepentingan individu harus dihormati, sehingga secara natural budaya "barat" ini memang sesuai dengan penegakan HaKI yang membutuhkan dukungan pelaku bisnis yang respek pada 
kepemilikan individual, termasuk di dalamnya kepemilikan intelektual. Karena itu penegakan HaKI di dunia barat jauh lebih berhasil daripada di dunia timur.

Tabel 2: Negara-negara yang Disebut Sebagai Sumber Pembajakan

\begin{tabular}{clc}
\hline No & \multicolumn{1}{c}{ Wilayah } & $\begin{array}{c}\text { Persentase wilayah } \\
\text { yang disebut } \\
\text { sebagai sumber } \\
\text { pembajakan }\end{array}$ \\
\hline 1 & Asia* $^{*}$ & $66 \%$ \\
2 & Eropa & $7 \%$ \\
3 & Afrika & $1 \%$ \\
4 & Amerika Latin & $7 \%$ \\
5 & Amerika Utara & $19 \%$ \\
\hline
\end{tabular}

Sumber: Bush et al.,1989; *) tanpa Cina Daratan

Dengan konteks seperti ini, pada dasarnya konsep HaKI merupakan fenomena budaya dan ekonomi, sehingga implikasi HaKI dapat dilihat melalui perspekstif budaya dan ekonomi dimana unsur budaya memiliki pengaruh signifikan terhadap tingkat keberhasilan penerapan HaKI. Hal ini dapat dijelaskan melalui kacamata "Hofstede's Cultural Dimension" dalam kaitannya dengan "individualism-collectivism dimensions".

Minat konsumen membeli produk bajakan tidak lepas dari sikapnya terhadap suatu produk. 'The reasoned-action theory' (Ajzen and Fishbein, 1980; p.16) menyebutkan bahwa kecenderungan perilaku seseorang dipandang sebagai fungsi dari dua faktor: sikap seseorang terhadap perilakunya dan sikap seseorang terhadap norma subjektifnya. Dalam penelitian ini, kecenderungan perilaku seseorang merefleksikan minat konsumen membeli produk bajakan bermerek, sedangkan sikap terhadap perilaku merefleksikan sikap terhadap legalitas pembelian produk bajakan bermerek dan persepsinya tentang kualitas produk bajakan, serta sikap terhadap norma subjekif merefleksikan sikap patuh hukum seseorang.

Perspektif teori ini mencakup bahwa minat konsumen membeli produk bajakan bermerek dipengaruhi juga oleh kesadaran terhadap norma hukum dan legalitas tindakan pembelian yang berkaitan dengan pelanggaran pemalsuan produk, realitas permintaan terhadap produk bajakan dan kualitas atau kinerja produk bajakan. Dari perspektif pemasaran, konsumen memiliki kebutuhan dasar (needs) yang harus dipenuhi (Kotler et al., 2001), dan dalam memenuhi kebutuhannya konsumen bisa saja menyadari maupun tidak menyadari status konsumsinya (Cordell et al., 1996).

Dengan dilandasi telaah terhadap hasil-hasil penelitian terdahulu dan teori di atas, berikut akan dikembangkan hipotesis yang berkaitan dengan pengaruh sikap terhadap patuh hukum, sikap terhadap pembelian produk bajakan, dan persepsi kinerja produk terhadap minat beli CD bajakan. Sementara status konsumsi dan demografi konsumen digunakan untuk melengkapi pembahasan temuan-temuan dari hasil analisis kuantitatif.

Minat membeli produk bajakan merupakan perilaku non-normatif. Sikap konsumen terhadap perilaku non-normatif berbeda dengan kejahatan khusus (Cordell et al., 1996). Perilaku non-normatif meliputi kejahatan kriminal dan kejahatan yang bersifat pasif. Kejahatan kriminal misalnya seperti pencurian di toko, atau merubah harga yang tertempel di barang yang dijual. Kejahatan pasif meliputi membiarkan kasir melakukan kesalahan menghitung jumlah uang yang harus dibayar, atau membiarkan kesalahan harga produk yang seharusnya lebih mahal (Jolson, 1974).

Toleransi dan partisipasi dalam perilaku non-normatif sering ditimbang melalui upaya netralisasi, dimana pelaku melepaskan dirinya dari tanggungjawab 
dengan mengabaikan kesalahan dari korban (Sykes \& Matza, 1957; DePaulo, 1986). Moral permisif ini juga merupakan refleksi dari moral standar ganda, karena konsumen berharap bahwa bisnis harus memiliki standard kualitas yang baik, namun konsumen tidak mau mengikuti standar yang diharapkan oleh konsumen sendiri (Chan et al., 1998). Dengan demikian, moral standar ganda dapat menjelaskan perilaku konsumen terhadap aktifitas perdagangan produk bajakan.

Cordell et al. (1996) mengatakan bahwa partisipasi konsmen didalam transaksi produk bajakan mendukung kegiatan illegal. Oleh karena itu, hubungan antara respek konsumen terhadap patuh hukum dan minat membeli produk bajakan dapat menjelaskan partisipasi konsumen dalam kegiatan perdagangan produk bajakan. Keterlibatan konsumen dalam perdagangan produk bajakan didukung oleh moral competency theory (Kohlberg, 1976) yang menyebutkan bahwa perilaku seseorang dikendalikan oleh rasa keadilan yang bersifat subjektif. Selanjutnya, dengan menggunakan the attitude model of legal socialization, Emler \& Reicher (1987) menemukan hubungan umum antara sikap terhadap otoritas institusional dan perilaku yang baik terhadap peraturan institusional. Model ini mengklarifikasi hirarki dari dampak hubungan antara sikap dan perilaku dalam kawasan hukum (Cordell et al., 1996).

Sementara,'The counterfeit product trade model' (Grossman \& Shapiro, 1988) mengatakan bahwa spekulasi tentang intensitas pembelian produk bajakan dengan harga murah menyebabkan perbedaan nilai antara produk bajakan dengan aslinya. Nilai prestis dapat dirasakan dari replikasi secara fisik produk yang dibajak untuk menunjukkan 'trademark' sebagai simbol status bagi yang memakainya. Namun, nilai kualitas produk bajakan biasanya sangat jauh dari produk aslinya (Cordell et al., 1996).
Selanjutnya Cordell et. al menyatakan bahwa karena produk bajakan secara fisik akan memberikan penampakan nilai prestis, tetapi karena kualitas produk seringkali tidak seimbang dengan aslinya, maka sangat beralasan ketika konsumen membeli produk bajakan, mereka menginginkan (berharapan) untuk dapat memiliki/mengkonsumsi produk yang kualitasnya kurang lebih mendekati aslinya.

Dengan alasan di atas, penelitian ini menduga bahwa: (1) Minat konsumen membeli produk bajakan dipengaruhi secara negatif oleh sikap patuh hukum konsumen; (2) Minat konsumen membeli produk bajakan dipengaruhi secara negatif oleh sikap terhadap legalitas pembelian produk bajakan, dan (3) Minat konsumen membeli produk bajakan bermerek dipengaruhi secara positif oleh persepsi kinerja produk bajakan yang kualitasnya relatif sebanding dengan produk aslinya. Penelitian ini juga akan menganalisis keterkaitan antara status sosial, gengsi, selera/citarasa, dan martabat konsumen dengan minat konsumen membeli CD bajakan.

Produk pada dasarnya juga memiliki kegunaan yang bersifat simbolik (Levy, 1978), seperti untuk menunjukkan status. Keinginan untuk mendapatkan status memotivasi perilaku konsumen (Eastman et al., 1999, Mason, 1981, Scitovsky, 1992). Karena itu produk yang dibeli konsumen bukan hanya untuk dimiliki, digunakan, tetapi juga untuk memperkuat kepribadiannya melalui penciptaan image berupa status sosial tertentu (mencakup gengsi, martabat, selera/citarasa), dan bagaiamana bentuk, tingkatan posisi dan hubungan status sosial yang mereka inginkan (Ewen, 1988; Braun \& Wicklund, 1988; Dawson \& Cavell, 1987).

Eastman et al., (1999, p. 42); Kilsheimer (1993, p. 341) mendefinisikan bahwa esensi dari konsep status konsumsi adalah 'konsumen membeli produk dimaksudkan untuk menunjukkan status 
dirinya kepada orang lain'. Tinggi rendahnya status/prestis seseorang ditentukan oleh seberapa besar penilaian orang lain terhadap produk yang dimiliki seorang konsumen (Dawson \& Cavell, 1987).

Dalam kasus studi produk bajakan, Field (2000) menemukan bahwa semakin tinggi tingkat konsumsi yang berkaitan dengan pemenuhan kebutuhan status semakin kuat kecenderungan konsumen untuk membeli produk asli. Jikapun mereka membeli produk bajakan, maka kualitas produk bajakan yang dibelinya harus mendekati aslinya (Cordell et al., 1996). Oleh karena itu, studi ini juga akan menganalisis keterkaitan antara status sosial, gengsi, selera/citarasa, dan martabat konsumen dengan minat konsumen membeli CD bajakan.

\section{METODE PENELITIAN}

Populasi penelitian ini adalah mahasiswa dari seluruh Indonesia yang diambil dari lima Universitas di Yogyakarta (UII, UGM, UMY, UAJ, UPN). Selain untuk memperoleh keragaman karakteristik demografi dan status konsumsi, pemilihan responden didasari dengan alasan bahwa mereka secara emosional sudah dewasa, bertanggungjawab penuh terhadap kepu- tusan membeli produk secara mandiri, baik sebagai pembeli maupun sebagai pengguna (Cordell et al., 1996; and Field, 2000), memiliki uang saku yang cukup untuk membeli produk $\mathrm{CD}$, mampu membedakan dengan baik antara $C D$ asli dan $C D$ bajakan yang mereka beli, memiliki informasi yang cukup baik berkaitan dengan perkembangan teknologi multimedia, dan memiliki pemahaman tentang etika dan hukum berkaitan dengan bisnis. Sampel penelitian ini sebanyak 500 (Sekaran, 1995) mahasiswa, yang diambil dengan metode quota-convenience sampling, yaitu masing-masing sebanyak 100 orang dari tiap Fakultas Ekonomi, di lima universitas tersebut. Analisis regresi berganda digunakan untuk melihat pengaruh Sikap Patuh Hukum, Sikap Legalitas Pembelian, dan Kinerja CD Bajakan terhadap Minat Beli CD Bajakan.

\section{HASIL DAN PEMBAHASAN}

Responden yang terjaring dalam penelitian ini adalah $57 \%$ pria dan $43 \%$ perempuan. Sebagian besar (60\%) dari mereka memiliki orang tua dengan penghasilan lebih Rp. 3 juta per bulan dan lebih dari separuh $(54 \%)$ responden memiliki uang saku kurang dari Rp. 750.000,- sebulan (Tabel 3).

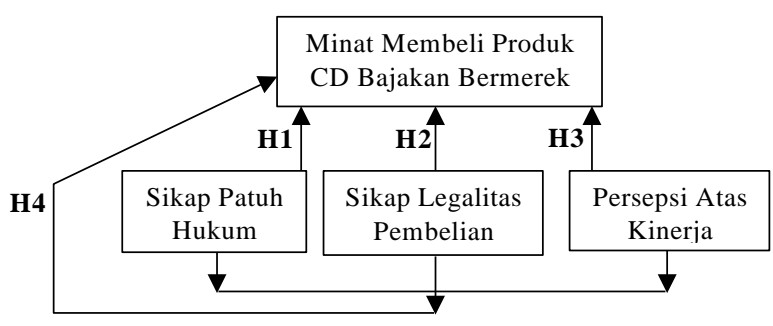

Gambar 1: Model Penelitian untuk Penelitian ini 
Ketika ditanyakan hal-hal terkait dengan keanggotaan klub, tradisi, dan agama, mereka memberi jawaban seperti disajikan dalam Tabel 4. Rresponden yang mengaku menjadi anggota suatu klub hanya $33 \%$ dan sebagian besar dari mereka $(58 \%)$ berpendapat bahwa keanggotaan pada suatu klub tidak mempengaruhi gaya hidup mereka, tetapi tradisi menurut sebagian besar responden (57\%) mempengaruhi gaya hidup. Sebagian besar responden menyatakan bahwa keanggotaan klub (81\%), tradisi tempat dimana mereka dibesarkan $76 \%$ ), dan agama (59\%) tidak mempengaruhi pembelian CD.

Tabel 3: Kategori Uang Saku Responden

\begin{tabular}{llcc}
\hline & \multicolumn{1}{c}{ Uang Saku } & Proporsi & Proporsi Kategori Uang Saku \\
\hline 1 & Kurang dari 500.000 & 19 & Kumulatif menengah bawah $54 \%$ \\
2 & $500.001-750.000$ & 35 & \\
3 & $750.001-1.000 .000$ & 25 & Kumulatif menengah atas $46 \%$ \\
4 & Lebih dar 1.000 .0001 & 21 & \\
\hline
\end{tabular}

Sumber: Data primer diolah

Tabel 4: Proporsi Responden yang Menyatakan Persetujuan Terhadap Pernyataan yang Diajukan Kepadanya

\begin{tabular}{clcc}
\hline \multirow{2}{*}{ No. } & PERNYATAAN & \multicolumn{2}{c}{$\begin{array}{c}\text { Proporsi responden yang } \\
\text { menyatakan }\end{array}$} \\
\cline { 3 - 4 } & & setuju (\%) & tdk Setuju \\
\hline 1 & Menjadi anggota suatu klub/perkumpulan & 33 & 67 \\
2 & Keanggotaan pada suatu klub mempengaruhi gaya hidup & 42 & 58 \\
3 & Keanggotaan klub mempengaruhi pembelian CD & 19 & 81 \\
4 & Tradisi tempat dimana responden dibesarkan mempengaruhi gaya hidup & 57 & 43 \\
5 & Tradisi tempat dimana responden dibesarkan mempengaruhi pembelian CD & 24 & 76 \\
6 & Agama mempengaruhi pembelian CD & 41 & 59 \\
\hline
\end{tabular}

Sumber: Data primer diolah

\section{Status Konsumsi}

Tabel 5: Proporsi Konsumen Atas Pertanyaan Terkait Status Konsumsi

\begin{tabular}{|c|c|c|c|}
\hline \multirow[t]{2}{*}{ No } & \multirow[t]{2}{*}{ PERNYATAAN } & \multicolumn{2}{|c|}{$\begin{array}{l}\text { Proporsi konsumen } \\
\text { yang menyatakan }\end{array}$} \\
\hline & & Setuju & Tdk setuju \\
\hline 1 & $\begin{array}{l}\text { Saya membeli CD asli karena akan meningkatkan/ mempengaruhi gengsi } \\
\text { atau status sosial saya. }\end{array}$ & 53 & 47 \\
\hline 2 & $\begin{array}{l}\text { Harga CD asli yang lebih mahal dari harga CD bajakan akan } \\
\text { mempengaruhi/meningkatkan gensi/ status sosial saya }\end{array}$ & 60 & 40 \\
\hline 3 & $\begin{array}{l}\text { Tinggi-rendahnya citarasa/ selera seseorang, salah satunya ditunjukkan } \\
\text { oleh pemakaian CD asli atau bajakan }\end{array}$ & 58 & 42 \\
\hline 4 & Pembelian CD bajakan akan merendahkan martabat saya & 53 & 47 \\
\hline 5 & Pembelian CD bajakan akan merendahkan citarasa/ selera saya & 50 & 50 \\
\hline 6 & Saya membeli CD bajakan karena harganya murah & 70 & 30 \\
\hline 7 & $\begin{array}{l}\text { Saya membeli } C D \text { bajakan karena kinerja } C D \text { bajakan tidak berbeda jauh } \\
\text { dengan kinerja } C D \text { aslinya }\end{array}$ & 67 & 33 \\
\hline
\end{tabular}

Sumber: primer diolah 
Responden yang setuju bahwa pembelian $\mathrm{CD}$ asli akan meningkatkan gengsi hanya 53\%, sementara yang setuju bahwa harga $\mathrm{CD}$ asli yang mahal akan meningkatkan gengsi adalah sebesar $60 \%$. Sebagian besar konsumen (58\%), sepakat bahwa tinggi rendahnya citarasa/selera ditunjukkan oleh pemakaian CD asli atau bajakan. Akan tetapi ketika dikonfrontir dengan pertanyaan "Apakah pembelian CD bajakan akan merendahkan citarasa/selera", proporsi responden yang setuju berubah menjadi 50\% (Tabel.5).

Proporsi jawaban dari pertanyaan 'Saya membeli CD bajakan karena harganya murah' dan 'Saya membeli CD bajakan karena kinerja CD bajakan tidak berbeda jauh dengan kinerja CD aslinya', nampaknya menisbikan sikap responden berkaitan dengan atribut psikologis seperti gengsi, citarasa/selera, dan martabat.

Bahkan proporsi responden yang menjawab setuju terhadap dua pertanyaan terakhir (masing-masing sebesar $70 \%$ dan $67 \%$ ) memberi gambaran yang lebih jelas lagi bahwa alasan ekonomis dan rasional-lah yang mendorong responden lebih berminat untuk membeli CD bajakan dari pada CD asli.

\section{Sikap Terhadap Kualitas CD Bermerek Kategori maupun jenis CD yang dimintakan penilaian kualitasnya oleh}

responden adalah CD-CD yang cukup populer dan diminati masyarakat Indonesia sehingga tidak mengherankan jika CD-CD tersebut dijadikan obyek pembajakan. Tujuan dari pertanyaan-pertanyaan seputar kategori dan jenis CD bermerek adalah untuk mengetahui seberapa kuat atau baik sikap konsumen terhadap CD-CD dimaksud. Pengetahuan tentang sikap konsumen ini kiranya akan sangat bermanfaat bagi pemasar maupun produsen CD asli bermerek dalam penyusunan strategi, kebijakan, maupun taktik produksi dan pemasaran yang harus dijalankannya sehingga dapat mengurangi kesempatan bagi tumbuh-suburnya bisnis produk bajakan.

Bila dicermati, temuan sikap responden terhadap $\mathrm{CD}$ bermerek tidak mengejutkan. Microsoft Windows dari kategori CD Program/Software dan EA Game dianggap oleh masing-masing $87 \%$ responden sebagai CD berkualitas. Barangkali, hal ini karena kedua jenis CD tersebut dianggap paling mampu memenuhi kebutuhan fungsional konsumen dan tingkat familiaritas penggunaan program/software yang ditawarkannya. Sementara itu, proporsi responden yang menyatakan bahwa Ben-Q dari kategori CD Audio adalah CD berkualitas hanya sebesar $62 \%$ responden dan merupakan proporsi terrendah dari sekuruh kategori dan jenis CD yang secara umum diketahui konsumen. 
Tabel 6: Proporsi Konsumen yang Bersikap Baik Terhadap Masing-masing Kategori Dan Jenis CD Bermerek

\begin{tabular}{clccll}
\hline \multicolumn{5}{c}{ KATEGORI DAN MEREK CD } \\
\hline No & CD Prog/Software & $\%$ & No & CD Game & $\%$ \\
1 & Microsoft Windows & 87 & 1 & EA Sport & 72 \\
2 & McAfee & 70 & 2 & EA Game & 87 \\
3 & Norton Anti Virus & 69 & 3 & Konami & 71 \\
4 & ACD See & 66 & 4 & Eidos & 69 \\
5 & Adobe Photshop & 87 & 5 & Ubisoft & 64 \\
\hline \multicolumn{7}{l}{} & & & & $\%$ \\
\hline 1 & CD Video & $\%$ & No & CD Audio & 75 \\
2 & Warner Bros & 74 & 1 & Sony BMG & 72 \\
3 & Paramount & 77 & 2 & Musica & 62 \\
4 & MGM & 69 & 3 & Ben-Q & 75 \\
5 & Miles Production & 71 & 4 & Bulletin & 73 \\
\hline
\end{tabular}

Sumber: primer diolah

Temuan Perhitungan Regresi

Hasil seluruh perhitungan regresi menunjukkan bahwa (Tabel.7), bila variabel-variabel independen secara individual digunakan untuk memprediksi minat beli, semua variabel tersebut menunjukkan pengaruhnya secara signifikan $(\mathrm{F}<0,05)$ terhadap minat beli CD bajakan. Namun sumbangan pengaruh (adjusted $\mathrm{R}^{2}$ ) variabel sikap patuh hukum dan sikap legalitas pembelian terhadap minat beli sangat kecil, yaitu masing-masing hanya sebesar $0,8 \%$ dan $6,5 \%$. Sementara pengaruh variabel kinerja CD bajakan cukup besar, yaitu $34,1 \%$.

Tabel 7: Ringkasan Hasil Perhitungan Regresi

\begin{tabular}{|c|c|c|c|c|c|c|}
\hline \multirow{2}{*}{ No } & \multirow{2}{*}{ Model } & \multicolumn{2}{|c|}{ Persamaan Regresi } & \multirow{2}{*}{ Adjusted R2 } & \multirow{2}{*}{ Sig.t. } & \multirow{2}{*}{ Sig. F } \\
\hline & & Unstandrdized $\beta$ & Standardized $\beta$ & & & \\
\hline 1 & $\begin{array}{c}\text { Constant } \\
\text { X1 }\end{array}$ & 3,006 & $-0,102$ & 0,008 & $\begin{array}{l}0,000 \\
0,022\end{array}$ & 0,022 \\
\hline 2. & $\begin{array}{c}\text { Constant } \\
\text { X2 }\end{array}$ & 3,364 & $-0,259$ & 0,065 & $\begin{array}{l}0,000 \\
0,000\end{array}$ & 0,000 \\
\hline 3. & $\begin{array}{c}\text { Constant } \\
\text { X3 }\end{array}$ & 1,599 & 0,585 & 0,341 & $\begin{array}{l}0,000 \\
0,000\end{array}$ & 0,000 \\
\hline 4. & $\begin{array}{c}\text { Constant } \\
\text { X1 } \\
\text { X2 } \\
\text { X3 }\end{array}$ & 1,742 & $\begin{array}{r}-0,008 \\
-0,040 \\
0,569\end{array}$ & 0,340 & $\begin{array}{l}0,000 \\
0,848 \\
0,350 \\
0,000\end{array}$ & 0,000 \\
\hline & $\begin{array}{c}\text { Dimana: } \\
\text { Independe } \\
\bullet \\
\bullet \\
\text { Dependen } \\
\bullet\end{array}$ & $\begin{array}{l}\text { iables: } \\
=\text { Sikap Patuh Hukum } \\
=\text { Sikap Legalitas Pen } \\
=\text { Kinerja CD Bajakan } \\
\text { able: } \\
=\text { Minat Konsumen N }\end{array}$ & elian & & & \\
\hline
\end{tabular}

Sumber: Hasil perhitungan regresi dengan SPSS 
Bila digunakan secara simultan, sikap patuh hukum, sikap legalitas pembelian, dan kinerja CD bajakan; merupakan prediktor yang signfikan $(\mathrm{F}<0,05)$ untuk minat beli $C D$ bajakan. Pengaruh yang disumbangkan oleh ketiga variabel itupun cukup besar, yaitu (adjusted $\mathrm{R}^{2}$ ) 34,0\%. Namun bila docermati, pengaruh sebesar itu hanya disumbangkan oleh variabel kinerja CD bajakan. Penjelasan mengenai hal ini diperoleh dari alpha uji $t$. Untuk variabel sikap patuh hukum dan sikap legalitas pembelian alpha mereka masing-masing sebesar 0,848 dan 0,350 , jauh di atas 0,05 , sehingga bisa dikatakan tidak memberi pengaruh terhadap minat beli CD bajakan. Sementara itu, alpha $t$ untuk variabel kinerja adalah 0,000 , jauh di bawah 0,05, sehingga dapat dikatakan berpengaruh secara signifikan terhadap minat beli $\mathrm{CD}$ bajakan. Dengan demikian dapat dikatakan, bahwa minat beli konsumen untuk CD bajakan dipengaruhi oleh kinerja CD bajakan dan bukan oleh sikap patuh hukum serta sikap legalitas pembelian.

Ditengah gencarnya upaya internasional untuk memerangi praktek pembajakan, temuan analisis regresi, baik regresi sederhana maupun simultan, menunjukkan bahwa konsumen kita masih menunjukkan perilaku kurang konsisten terhadap aspek hukum dan legalitas terkait dengan pembelian CD bajakan. Sebaliknya, aspek kinerja produk $\mathrm{CD}$ bajakan menunjukkan pengaruhnya yang signifikan, yaitu $34 \%$, terhadap minat beli konsumen. Temuan ini tentu memprihatinkan. Penjelasan mengenai sebab-sebab yang mendasari perilaku demikian akan disajikan berikut ini:

Pertama, dari hasil analisis regresi berganda didapatkan temuan bahwa hanya variabel kinerja yang menjadi pendorong konsumen untuk membeli $\mathrm{CD}$ bajakan (Tabel 7). Sehingga ada indikasi bahwa sikap patuh hukum dan sikap legalitas pembelian produk CD asli tereduksi oleh kinerja CD bajakan, dan menyebabkan konsumen tidak konsisten terhadap norma normatifnya (hukum dan legalitas) yang seharusnya ditaati. Dengan demikian, sikap konsumen dapat berubah karena adanya faktor eksternal berupa kinerja produk CD bajakan yang kinerjanya relatif sama dengan CD aslinya, disamping harganya yang murah (Tabel 5).

Kedua, dari analisis deskriptif demografis didapat temuan menarik lain, dimana harga dan kinerja produk CD bajakan juga mampu mereduksi kebutuhan konsumen akan gengsi, status sosial, cita rasa/selera dan martabat konsumen. Hal ini terungkap dari banyaknya responden yang setuju bahwa pembelian CD asli dan/atau harga CD asli yang lebih mahal akan meningkatkan gengsi. Mereka juga sepakat bahwa pemakaian CD asli atau bajakan akan mempengaruhi tinggi rendahnya citarasa/selera maupun martabat seseorang. Meski demikian, mereka masih tetap berminat untuk membeli $\mathrm{CD}$ bajakan. Harga CD bajakan yang murah dan kualitasnya yang tidak jauh berbeda dengan CD aslinya, agaknya telah mampu mendorong konsumen untuk mengabaikan gengsi, citarasa, maupun martabat yang mungkin diperoleh jika mereka membeli dan memiliki CD asli. Betapa pun, kualitas dan harga $\mathrm{CD}$ asli yang tinggi memang pantas menjadi salah satu simbol gengsi atau martabat maupun citarasa/selera. Akan tetapi, dengan kualitas yang hanya sedikit lebih tinggi dari CD bajakan sementara harganya jauh lebih mahal, pembelian CD asli tidak menawarkan nilai secara esensial maupun simbolis yang signifikan pada konsumen. Hal ini karena produk CD tidak secara pisik dan melekat pada diri konsumen sebagai simbol statusnya seperti halnya produk baju, celana, jam tangan, mobil dll.

Uang saku sepertinya menjadi alasan ekonomis yang mendasari minat atau keputusan konsumen membeli CD bajakan. Sebagian besar responden, yaitu sebanyak 
$54 \%$, ternyata tergolong memiliki uang saku pada kategori menengah kebawah (lihat Table 3). Dengan uang saku dibawah Rp. 750.000 ,- per bulan, kiranya sulit bagi mereka mengalokasikan uang saku untuk membeli CD asli. Namun, jika dicermati lebih dalam, ternyata ada fakta lain yang menarik dan terungkap dalam penelitian ini. Tampaknya pembelian CD bajakan bukan hanya manopoli konsumen golongan menengah ke bawah. Tabel 3 di atas mengindikasikan bahwa sebagian konsumen yang memiliki uang saku lebih dari Rp 750.000 ,- ada yang tertarik untuk membeli CD bajakan. Indikasi ini diperoleh dari hasil membandingkan antara proporsi konsumen yang berpendapatan Rp. 750,000,- ke bawah (54\%) dengan proporsi konsumen yang sepakat dengan pernyataan bahwa pembelian CD bajakan dilakukan karena harganya murah $(70 \%)$ dan kinerjanya mendekati aslinya (67\%). Dengan kata lain, proporsi yang disebut terakhir melampaui proporsi konsumen dengan pendapatan menengah ke bawah. Jadi, uang saku ternyata tidak memberi penjelasan tuntas berkenaan dengan perilaku tersebut di atas. Yang nampak jelas disini ialah konsumen sadar bahwa pembelian $\mathrm{CD}$ asli dapat meningkatkan status sosial, gengsi, martabat, atau citarasa, namun minat yang mereka miliki tetap mengarahkan mereka untuk membeli CD bajakan. Temuan lain dari analisis demografis mengindikasikan bahwa keanggotaan konsumen pada suatu klub, dan tradisi dimana konsumen dibesarkan, serta agama yang dianutnya ternyata tidak memiliki pengaruh terhadap minat mereka untuk pembelian CD bajakan (lihat Tabel 4). Semuanya itu merupakan indikasi bahwa peran faktor-faktor eksternal konsumen yang secara teoritis dapat digunakan untuk membangun dan mengembangkan sikap atau perilaku mereka masih belum signifikan.

Ketiga, temuan di atas penting artinya baik bagi para produsen/pemasar produk asli maupun para pembuat kebijakan publik. Apa yang bisa dipelajari dari temuan di atas ialah value berupa status sosial, gengsi, martabat, citarasa/selera yang ditawarkan oleh suatu produk tidak akan memiliki arti yang signifikan bila manfaat atau fungsi esensial (makna/fungsi simbolis) dari produk dimaksud tidak berbeda secara signifikan dari produk pesaing atau substitusinya. Indikasi statemen di atas yang terungkap dalam penelitian ini adalah bahwa sikap patuh hukum dan sikap legalitas terhadap pembelian $\mathrm{CD}$ bajakan -yang potensial mengarahkan konsumen untuk dapat memenuhi kebutuhan psikologis berupa status sosial, gengsi, martabat, dsb.- menjadi inkonsisten ketika harga CD bajakan yang murah dan kinerja $\mathrm{CD}$ bajakan yang mendekati kinerja $\mathrm{CD}$ aslinya dijadikan atribut alternatif bagi pertimbangan kognitif atau rasional responden. Jadi, sikap patuh hukum dan sikap legalitas pembelian saja belum mampu mencegah mereka untuk membeli produk bajakan.

Keempat, kecenderungan responden untuk mengabaikan aspek hukum dan legalitas pembelian juga mengindikasikan bahwa konsumen berpartisipasi secara aktif dan signifikan pada perdagangan CD bajakan. Dengan kata lain, perilaku tersebut menunjukkan bahwa -dengan moral subyektif yang inkonsisten- konsumen masih menjadi kendala yang serius karena memiliki komitmen yang rendah terhadap pemberantasan produk bajakan.

Pembahasan di atas mengarahkan kepada pengertian bahwa alasan ekonomis dan rasional seperti harga dan kinerja CD bajakan yang cukup tinggi memang merupakan alasan kuat yang telah mampu mengalihkan pilihan konsumen dari membeli CD asli ke CD bajakan. Disamping itu, bukan kedua alasan itu saja yang telah membentuk perilaku tersebut. Namun ada faktor lainnya seperti budaya (institusi hukum dan pendidikan), tradisi (sumber 
pembentukan perilaku sosial permisif atau tidak permisif), klub (kelompok dan/atau individu rujukan), dan agama (sumber ajaran moral dan perilaku positif) yang mempengaruhi sumber perilaku ilegal tersebut. Ada indikasi bahwa institusi hukum, institusi pendidikan, institusi agama, kelompok rujukan, dan tradisi permisif terhadap perilaku ilegal berkait dengan bisnis produk bajakan.

Merujuk kepada pendapat para ahli, seperti tersebut dalam landasan teori penelitian ini, aspek-aspek seperti institusi hukum, klub, tradisi serta agama memiliki pengaruh (positif maupun negatif) dalam pembentukan maupun pengembangan sikap atau perilaku seseorang terhadap suatu produk. Pembentukan dan pengembangan sikap atau perilaku dimaksud dapat menghasilkan dampak begitu signifikan terhadap keberhasilan atau kegagalan pemasaran. Apabila faktor-faktor perilaku konsumen tersebut dijadikan sebagai dasar pertimbangan dalam penyusunan strategi perusahaan, terutama strategi pemasaran, maka secara teoritis akan menyumbang tingkat keberhasilan kinerja perusahaan yang direpresentasikan dalam bentuk profit. Selanjutnya perusahaan yang berhasil tersebut akan menjadi aset penting bagi negara dilihat dari kontribusinya dalam bentuk kesempatan kerja dan sumbangan pajak. Disamping itu, kinerja perusahaan yang baik akan memudahkan dalam merealisasikan tanggungjawab sosialnya (corporate social responsibility) untuk meningkatkan kualitas hidup kepada setiap unsur stake holder-nya. Dengan demikian penegakan HaKI yang pada akhirnya akan menciptakan kondisi yang kondusif bagi tumbuh-kembangnya kinerja perusahaan yang baik perlu diupayakan dengan sungguh-sungguh.

Menurut temuan sejumlah penelitian tersebut dalam landasan teori penelitian ini, upaya penegakan HaKI ternyata menghadapi tantangan yang cukup kom- pleks karena mencakup sikap maupun lingkungan eksternal konsumen yang belum menunjukkan komitmen yang kuat terhadap pemberantasan bisnis bajakan. Meski demikian, mengingat arti pentingnya perlindungan HaKI baik bagi penemu, produsen, maupun negara begitu signifikan, upaya penegakan HaKI, baik dalam lingkup internasional maupun lingkup suatu negara, masih perlu diupayakan. Agar upaya tersebut berhasil maka upaya pembentukan dan pengembangan sikap patuh hukum dan legalitas pembelian suatu produk (termasuk CD) perlu memanfaatkn institusi hukum, pengaruh klub, tradisi, maupun agama dalam penegakan HaKI. Dengan kata lain selain polisi dan hakim- para pejabat negara, tokoh organisasi, masyarakat, agama, dan para tokoh pendidik, perlu dilibatkan secara aktif -dimana pemerintah sebagai motor penggeraknya- dalam upaya mengurangi kegiatan bisnis ilegal berkait dengan pembajakan. Peran aktif yang diperlukan adalah berupa kerjasama, bukan hanya dalam hal memberi penerangan, akan tetapi juga dalam hal memberi contoh nyata berupa tindakan tidak membeli ataupun memakai CD bajakan karena masyarakat kita adalah masyarakat yang paternalistik, masyarakat yang mencontoh apa-apa saja yang dilakukan oleh panutan mereka. Para pejabat berwenang dan para tokoh masyarakat harus pula memiliki komitmen yang kuat untuk tidak mentolerir munculnya bisnis produk bajakan, baik melalui sosialisasi peraturan terkait, persuasi maupun pelaksanaan penegakan hukum.

Disisi lain, dari para pelaku bisnis yang terlibat mulai dari penemu, pabrikan, serta mata rantai perdagangan produk asli, juga harus terlibat secara aktif dalam mengurangi dan bahkan meniadakan tindakan dalam dunia bisnis ilegal yang dilakukan oleh para konsumen, dengan melakukan serangkaian tindakan kebijakan dan strategi seperti value pricing (kaualitas 
tinggi, harga murah, inovasi teknologi yang terus menerus), mengingat alasan utama responden mebeli CD bajakan karena faktor ekonomi.

\section{SIMPULAN DAN SARAN}

Para konsumen menganggap bahwa pembelian $\mathrm{CD}$ asli akan meningkatkan gensi, status sosial, citarasa/seleran, dan martabatnya. Namun, harga CD bajakan yang murah sementara kinerjanya relatif tidak kalah jauh dari kinerja CD asli sehingga membuat perbedaan manfaat atau fungsi antara CD asli dan bajakan menjadi tidak esensial- telah membuat konsumen tetap berminat untuk untuk membeli CD bajakan meski untuk itu konsumen harus mereduksi kebutuhannya akan gensi, status sosial, citarasa/seleran, dan martabatnya. Fakta lain yang terungkap adalah bahwa, ternyata, pengorbanan semacam ini bukan hanya dilakukan oleh konsumen yang secara ekonomis (uang saku) kurang mampu, akan tetapi juga oleh sebagian konsumen yang memiliki kemampuan ekonomis.

Tidak signifikannya pengaruh sikap patuh hukum dan sikap legalitas pembelian terhadap minat beli untuk CD bajakan menunjukkan bahwa konsumen memiliki peran aktif dan signifikan pada perdagangan CD bajakan. Temuan ini mengungkapkan bahwa moral subyektif konsumen yang inkonsisten telah menyebabkan konsumen menjadi kendala yang serius karena mereka memiliki komitmen yang rendah terhadap pemberantasan produk (CD) bajakan.

Sebab lain dari perilaku konsumen dimaksud adalah keberadaan institusi hukum, institusi pendidikan, institusi agama, dan tradisi serta organisasi sosial lainnya (seperti klub dimana konsumen menjadi anggotanya) tidak memberi pengaruh terhadap minat konsumen untuk membeli CD bajakan. Fakta ini menunjukkan bahwa institusi-institusi tersebut bersikap permisif terhadap bisnis (khususnya CD) bajakan.

Berdasarkan temuan ini maka penegakan peraturan HaKI perlu diupayakan dengan serius. Penelitian ini menemukan bahwa sikap patuh hukum dan sikap legalitas pembelian belum cukup untuk meredam minat konsumen untuk membeli CD bajakan. Oleh karena itu, agar upaya penegakan HaKI efektif, khususnya untuk bisnis CD, pemerintah perlu melibatkan secara aktif para tokoh masyarakat, tokoh pendidikan, tokoh agama, public figure, opinion leader, dan organisasi atau kelompok-kelompok dimana pemerintah bertindak sebagai motor penggeraknya. Kerjasama ini dilakukan sejak dari sosialisasi peraturan HaKI, keteladanan untuk tidak membeli dan memakai produk bajakan, dan penegakan hukum atau pemberian sanksi yang seirus.

Dalam penelitian ini juga ditemukan konsumen memiliki kesadaran bahwa kualitas CD asli dan harganya yang tinggi dapat dijadikan sebagai salah satu alat pemuas untuk kebutuhan status sosial, gengsi, selera/citarasa, dan martabat. Namun harga yang murah dan kinerja produk CD bajakan yang tidak berbeda jauh dari kinerja produk asli telah membuat konsumen mau mengorbankan kebutuhan akan status sosial, gengsi, citarasa/selera, dan martabatnya tersebut. Oleh karena itu, kiranya para produsen juga perlu terlibat dalam upaya meniadakan, minimal mengurangi, aktifritas bisnis $\mathrm{CD}$ bajakan. Upaya ini dapat dilakukan melalui upaya mengefisienkan biaya saluran distribusi, dan proses lainnya sehingga produsen dapat menarapkan strategi value-pricing.

\section{DAFTAR PUSTAKA}

Ajzen, I \& Fishbein, M. 1980, Understanding Attitudes and Predicting Social Behavior, Englewood-Cliffs, Prentice-Hall, New York. 
SIIERGH Vol. 10 No. 2, JUNI 2008: 199 - 214

Bazan, P. 1999,'The Rise of Counterfeiting and Trade Mark Piracy', in Managing Intellectual Property.

Bloch, P. H.; Bush, R. F. \& Campbell, L. 1993,'Consumer Accomplices in Product Counterfeiting, A Demand Side Investigation', Journal of Consumer Marketing, vol. 10, no. 4, pp. 27-36.

Braun, O.L. \& Wicklund, R.A. 1988,'Psychological Antecedents of Conspicuous Consumption', Journal of Economic Psychology, June, pp. 161-187.

Bush, R. F., Bloch, P. H. \& Dawson, S. 1989, 'Remedies for Product Counterfeiting', Business Horizon, January-February, pp. 59-65.

Chan, A., Wong, S. \& Leung, P. 1998, ' Ethical beliefs of Chinese consumers in Hong Kong’, Journal of Business Ethics, vol.17, no. 11, pp. 1163-1170.

Cordell, V. V., Wongtada, N. \& Kieschnik, Jr., R. L. 1996, 'Counterfeit Purchase Intentions: Role of Lawfulness Attitudes and Product Traits as Determinants', Journal of Business Research, vol. 35, pp. 41-53.

Dawson, S. \& Cavell, J. 1987,' Status Recognition in the 1980s: Invidious Distinction Revisited', in Advances in Consumer Research, vol. 14, Mellanie Wallendorf \& Paul Anderson (eds.), Provo, UT.: Association for Consumer Research, pp. 487491.

d'Astous, A. \& Gargouri, E. 2001, 'Consumer Evaluations Of Brand Imitations', European Journal of Marketing, vol. 35, no. 1/2, pp. 153-167.

Delener, N. 2000, 'International Counterfeit Marketing: Success Without Risk', Review of Business, spring, pp. 16-20.

.DePaulo, P. J. 1986,'Ethical Perception of Deceptive Tactics Used by Salesperson and Consumer: A Double Standard', Proceedings of the American Psychological Association, American Psychological Association, Washington DC, pp. 101-103.

Eastman, J. K., Goldsmith, R. E. \& Flynn, L. R. 1999,'Status Consumption in Consumer Behavior: Scale Development and Validation', Journal of Marketing Theory and Practice, vol. 7, no. 3, pp. 41-51.

Emler, N. \& Reicher, S. 1987, 'Orientation to Institutional Authority in Adolescence', Journal of Moral Education, vol. 16, no. 2, pp. 108-116.

Ewen, S. 1988, All Consuming Images, Basic Books, New York

Fareshti N. D. 2003,'Pelaku Pembajak vs Konsumsi Product Bajakan,'Pikiran Rakyat, available: http://www.pikiranrakyat.com/cetak/0703/16/0804.htm

Field, J. R. B. 2000,'An Empirical Investigation of Consumers' Perceptions and Purchase Intentions of Counterfeit Products: A Means-End Chain Analysis', a PhD Dissertation, Mississippi State University, available: http:// wwwlib.umi.com/ dissertations/ preview all/ 9991310. 
Grossman, G. M. \& Shapiro, C. 1988, 'Foreign Counterfeiting of Status Goods', The Quarterly Journal of Economics, February, pp. 79-100.

Harvey, M. G. \& Ronkainen, I. A. 1985,'International Counterfeiters: Marketing Success Without the Cost or The Risk', Columbia Journal of World Business, vol. 20, Fall, pp. 37-45.

Jolson, M. A. 1974,'Consumers as Offenders, Journal of Business Research, vol. 2, pp. 8998.

Kholberg, L. 1976, Moral Stages and Moralization: The Cognitive Development Approach, in Moral Developm,ent and Behavior: Theory, Research and Social Issues, Thomas Lickona (ed.), Holt, Rinehart and Winston, New York.

Kilsheimer, J. 1993, Status Consumption:The Development and Implications of a Scale Measuring the Motivation to Consume for Status, a $\mathrm{PhD}$ dissertation, Marketing Faculty at Florida State University, Florida.

Kotler, P., Brown, L., Adam, S. \& Armstrong, G. 2001, Marketing, Australia: Prentice Hall.

Lai, K. K. Y. \& Zaichkowsky, J. L. 1999,'Brand Imitation: Do the Chinese have different views?' Asia Pacific Journal of Management, vol. 16, pp. 179-192.

Levy, S. 1978, Marketplace Behaviour: Its Meaning for Management, AMACOM, New York.

Lynch, S. 2002,'Commercial Counterfeiting', Paper prepared for Trade Inspections Conference, October 23, pp. 1-23.

Masland, T. \& Marshall, R. 1990, 'A Really Nasty Business', Newsweek, vol. 116, Nov. 5, pp. 36-37,43.

Mason, R.S. 1981, Conspicuous Consumption: a Study of Exceptional Consumer Behaviour, St. Martin's Press, New York.

Nash, T. 1989, 'Only Imitation? The Rising Cost of Counterfeiting', Director, May, pp. 6469.

Nia, A. \& Zaichkowsky, J. L. 2000, 'Do Counterfeits Devalue The Ownership of Luxury Goods?' Journal of Product and Brand Management, vol. 9, no. 7, pp. 485-497.

Olsen, J. E. \&Granzin, K. L. 1992, 'Gaining Retailers' Assistance in Fighting Counterfeiting: Conceptualization and Empirical Test of a Helping Model', Journal of Retailing, vol. 68, Spring, pp. 90-111.

Phau, I., Prendergast, G. \& Chuen, L. H. 2001,'Profiling Brand-Piracy-Prone Consumers: An Exploratory Study in Hongkong's Clothing Industry', Journal of Fashion Marketing and Management, vol. 5, no. 1, pp. 45-55.

Sanda, A. 2003,'Ekonomi Jakarta, Konsumerisme dan Property', Kompas, 22 Desember 2003, available: http://www.kompas.com/kompas-cetak/0312/22/sorotan/ 756849.htm 
SIIERGH Vol. 10 No. 2, JUNI 2008: 199 - 214

Sekaran, U. 2003, Research Methods for Business. A Skill Building Approach, John Wiley \& Son, USA.

Scitovsky, T. 1945,'Some Consequences of the Habit of Judging Quality by Price', Review of Economics Studies, vol. 12, Winter, pp. 100-105.

Sivacek, J. \& Crano, W. D. 1982,'Vested Interest as Moderatror of Attitude behaviour consistency', Journal of Personality and Social Psychology, vol. 43, pp. 210-221.

Sykes, G. M. \& Matza, D. 1957,'Techniques of Neutralization: a Theory of Delinquency', American Sociological review, vol. 22, pp. 664-670.

Vithlani, H. 1998,'The Economic Impact of Counterfeiting', Economic Co-operation and Development (OECD), Head of Publication Service, France.

Wee, C. H., Tan, S. J. \& Cheok, K. H. 1996, 'Non-Price Determinants of Intention to Purchase Counterfeit Goods', International Marketing Review, vol. 12, no. 6, pp. 13-46. 